\title{
Dermatomyositis associated with celiac disease: Response to a gluten-free diet
}

\author{
Min Soo Song $M D^{1}$, David Farber $\mathrm{MD}^{2}$, Alain Bitton $\mathrm{MD}^{3}$, Jeremy Jass BSc (Lon) MD FRCPA DSc (Lon) ${ }^{4}$, \\ Michael Singer BA MD ${ }^{5}$, George Karpati MD ${ }^{6}$
}

\begin{abstract}
MS Song, D Farber, A Bitton, J Jass, M Singer, G Karpati. Dermatomyositis associated with celiac disease: Response to a gluten-free diet. Can J Gastroenterol 2006;20(6):433-435.

The association between dermatomyositis and celiac disease in children has been well documented. In the adult population, however, the association has not been clearly established. A rare case of concomitant dermatomyositis and celiac disease in a 40-year-old woman is presented. After having been diagnosed with dermatomyositis and iron deficiency anemia, this patient was referred to the gastroenterology clinic to exclude a gastrointestinal malignancy. Blood tests revealed various vitamin deficiencies consistent with malabsorption. The results of gastroscopy with duodenal biopsy were consistent with celiac disease. After she was put on a strict glutenfree diet, both nutritional deficiencies and the dermatomyositis resolved. The patient's human leukocyte antigen haplotype study was positive for DR3 and DQ2, which have been shown to be associated with both juvenile dermatomyositis and celiac disease. It is suggested that patients with newly diagnosed dermatomyositis be investigated for concomitant celiac disease even in the absence of gastrointestinal symptoms.
\end{abstract}

\section{La dermatomyosite associée à la maladie cœ-liaque : La réponse à un régime sans gluten}

Key Words: Celiac disease; Dermatomyositis; Gluten

$\mathrm{D}^{\mathrm{s}}$ ermatomyositis is a rare clinical entity characterized by symmetric proximal muscle weakness and distinctive skin manifestations (1). Although most cases are idiopathic, the disease commonly presents in association with another connective tissue disorder. It may also present as a paraneoplastic syndrome associated with, for example, ovarian or gastrointestinal malignancies.

Celiac disease is a malabsorption syndrome resulting from a small-bowel enteropathy related to the intake of dietary gluten in susceptible individuals (2-4). Gluten is thought to cause both direct and immune-mediated toxicity. Although most cases are discovered in early childhood, the diagnosis of celiac disease in adults is not uncommon. The clinical presentation of celiac disease in the adult population is more variable, however, with a tendency toward atypical features. Moreover, celiac disease has been associated with other autoimmune disorders including thyroiditis, autoimmune hepatitis, Addison's disease, and pernicious anemia $(5,6)$. There is also a strong association between celiac disease and type I diabetes, and dermatitis herpetiformis.

There have been numerous reports suggesting an association between polymyositis and celiac disease $(7,8)$. An association between juvenile dermatomyositis and celiac
L'association entre la dermatomyosite et la maladie coliaque est bien documentée chez les enfants. Au sein de la population adulte, cependant, cette association n'est pas clairement établie. Un rare cas de dermatomyosite concomitante à une maladie cœeliaque est présenté chez une femme de 40 ans. Après un diagnostic de dermatomyosite et d'anémie ferriprive, la patiente a été aiguillée vers une clinique de gastroentérologie pour exclure le risque de malignité gastro-intestinale. Les analyses sanguines ont révélé diverses carences vitaminiques compatibles avec une malabsorption. Les résultats de la gastroscopie avec biopsie duodénale suggéraient une maladie cœliaque. Après avoir entrepris un régime sans gluten strict, tant les carences nutritionnelles que la dermatomyosite ont disparu. L'étude d'haplotypes HLA était positive au DR3 et au DQ2, dont l'association avec la dermatomyosite juvénile et la maladie coliaque est démontrée. On suggère que les patients atteints d'une dermatomyosite nouvellement diagnostiquée fassent l'objet d'explorations pour déceler une maladie coliaque concomitante, même en l'absence de symptômes gastro-intestinaux.

\footnotetext{
${ }^{1}$ Department of Internal Medicine, McGill University Health Centre, Montreal; ${ }^{2}$ Department of Gastroenterology, L'Hôpital Cité-de-la-Santé,

Laval; ${ }^{3}$ Department of Gastroenterology; ${ }^{4}$ Department of Pathology, McGill University Health Centre; ${ }^{5}$ Department of Dermatology,

Sir Mortimer B Davis Jewish General Hospital; ${ }^{6}$ Department of Neurology, McGill University Health Centre, Montreal, Quebec

Correspondence: Dr Alain Bitton, Department of Gastroenterology, Royal Victoria Hospital, 687 Pine Avenue West, Montreal,

Quebec H3A 1A1. Telephone 514-843-1616, fax 514-843-1421, e-mail alain.bitton@muhc.mcgill.ca

Received for publication December 15, 2005. Accepted January 4, 2006
} 
TABLE 1

Patients with concomitant celiac disease and dermatomyositis

\begin{tabular}{|c|c|c|c|}
\hline Characteristics & $\begin{array}{c}\text { Song et al } \\
\text { (present study) }\end{array}$ & Marie et al (12) & $\begin{array}{l}\text { lannone and } \\
\text { Lapadula (13) }\end{array}$ \\
\hline Patient's age & 40 years & 63 years & 48 years \\
\hline Ethnicity & Irish & Not identified & Not identified \\
\hline First diagnosis & Dermatomyositis & Dermatomyositis & Celiac disease \\
\hline $\begin{array}{l}\text { Length of time } \\
\text { between } \\
\text { diagnoses }\end{array}$ & 10 months & 2 years & 3 years \\
\hline Duodenal biopsy & Yes & Yes & Yes \\
\hline $\begin{array}{l}\text { Antiendomysial } \\
\text { antibodies }\end{array}$ & Negative & Negative & Positive \\
\hline SBFT & $\begin{array}{l}\text { Yes, consistent with } \\
\text { celiac disease }\end{array}$ & No & No \\
\hline HLA typing & DR3, DQ2 & Not available & Not available \\
\hline \multirow[t]{4}{*}{ Treatment } & Gluten restriction & Steroid (2 years) & Gluten restriction \\
\hline & $\begin{array}{l}\text { Methylprednisolone } \\
\text { (2 doses) }\end{array}$ & Gluten restriction & $\begin{array}{l}\text { Methyl- } \\
\text { prednisolone } \\
\text { (2 weeks) }\end{array}$ \\
\hline & & & $\begin{array}{l}\text { Daily prednisone, } \\
\text { taken orally }\end{array}$ \\
\hline & & & Daily cyclosporin A \\
\hline
\end{tabular}

HLA Human leukocyte antigen; SBFT Small-bowel follow-through

treatment with mild and potent topical steroids, as well as photoprotection. The skin biopsy was consistent with dermatomyositis. Neurological examinations demonstrated reduced power in the proximal upper extremities. There was no muscle tenderness although repetitive activity provoked aching in the deltoids.

Initial laboratory data showed a mild normocytic anemia (hemoglobin concentration $119 \mathrm{~g} / \mathrm{L}$ ) with elevated red cell distribution width (20.7\%). Leukocyte and platelet counts were normal. Serum creatine kinase activity was normal. Serum alkaline phosphatase was elevated at $249 \mathrm{U} / \mathrm{L}$ (bone fraction $226.7 \mathrm{U} / \mathrm{L}$, liver fraction $22.3 \mathrm{U} / \mathrm{L}$ ); serum total bilirubin, gamma glutamyl transferase and alanine aminotransferase levels were normal. Antinuclear antibody was positive with a titre of 1:40, speckled pattern. Other autoimmune markers were negative including anti-DNA antibody, anti-Smith, anti-Ro, anti-La, anti-RNP and anti-Scl 70. Anti-Jo-1 antibody was also negative but an electromyogram of the left deltoid revealed abnormalities consistent with dermatomyositis. This diagnosis was subsequently confirmed by the muscle biopsy, which showed interstitial inflammation with prominence of the capillary endothelial cells, and small regions in the muscle where capillarity was reduced.

The patient was referred to the gastroenterology clinic to rule out an underlying gastrointestinal malignancy, a routine measure in adult dermatomyositis. Meanwhile, therapy with intravenous pulse methylprednisolone $(500 \mathrm{mg})$ was initiated. In total, the patient received only two steroid doses. The clinical course was complicated by severe hypocalcemia (serum calcium level $1.16 \mathrm{mmol} / \mathrm{L}$ ) with carpopedal spasm following the ingestion of oral fleet phosphosoda in preparation for colonoscopy. This episode required brief admission to the intensive care unit, where she was treated with intravenous calcium. Subsequent laboratory testing revealed worsening anemia (hemoglobin concentration $101 \mathrm{~g} / \mathrm{L}$ ) with evidence of combined deficiencies of iron (serum iron level $4 \mu \mathrm{mol} / \mathrm{L}$, total iron binding capacity $78.9 \mu \mathrm{mol} / \mathrm{L}$ and serum ferritin $5 \mu \mathrm{g} / \mathrm{L}$ ) and folate (serum folate $3 \mathrm{nmol} / \mathrm{L}$, red blood cell folate $14 \mathrm{nmol} / \mathrm{L}$ ); vitamin $B_{12}$ levels were normal. In addition, there were deficiencies in some fat-soluble vitamins (serum vitamin $\mathrm{E}$ level $6 \mu \mathrm{mol} / \mathrm{L}$, carotene less than $2 \mu \mathrm{mol} / \mathrm{L}$ ). The international normalized ratio was elevated at 1.46 , reflecting a lack of vitamin K. Serum protein and albumin levels were low $(64 \mathrm{~g} / \mathrm{L}$ and $33 \mathrm{~g} / \mathrm{L}$, respectively). Laboratory workup further demonstrated secondary hyperparathyroidism with a parathyroid hormone level of $505 \mathrm{pg} / \mathrm{mL}$ (normal $10 \mathrm{pg} / \mathrm{mL}$ to $45 \mathrm{pg} / \mathrm{mL}$ ); serum $1-25$ vitamin $\mathrm{D}$ was greater than $100 \mathrm{pg} / \mathrm{mL}$ (normal $15 \mathrm{pg} / \mathrm{mL}$ to $45 \mathrm{pg} / \mathrm{mL}$ ).

The patient underwent upper gastrointestinal endoscopy with a small-bowel biopsy. Pathology revealed severe villous atrophy, crypt hyperplasia, and moderate chronic inflammation in the lamina propria, mild intraepithelial lymphocytosis, mild degenerative change in surface epithelium and focal acute inflammation in the lamina propria. Small-bowel follow-through revealed dilation and segmentation of the jejunum, consistent with celiac disease. Antiendomysial antibody was negative. Serum human leukocyte antigen typing yielded the following association: A1/A2, B8/B15, C3, DR3/DR4 and DQ2/DQ8.

The patient was placed on a gluten-free diet, along with supplemental iron, folate and calcium. With strict dietary adherence, she showed remarkable improvement as demonstrated by an approximately $11 \mathrm{~kg}$ weight gain, restoration of full power and complete resolution of the skin lesions within six to nine months. In addition, all laboratory findings normalized and there was a reversal of all muscle weakness. A repeat small-bowel biopsy, seven months after the dietary modification, remained abnormal but showed clear improvement.

Interestingly, the patient's twin sister, who was being investigated for hypocalcemia and vague abdominal complaints, was also diagnosed with celiac disease after a small-bowel biopsy, but there was no report of skeletal muscle weakness.

\section{DISCUSSION}

We describe a 40-year-old woman who presented with weight loss, skin lesions and muscle weakness attributed to dermatomyositis. She was referred for a gastrointestinal malignancy workup. She had no overt gastrointestinal complaints. Unlike in juvenile celiac disease, the clinical presentation of celiac disease in adults is more variable, with a tendency toward atypical features including unexplained iron deficiency anemia, dental enamel hypoplasia, epilepsy with cerebral calcifications, recurrent aphthous ulceration or metabolic bone disease (14).

An association between celiac disease and juvenile dermatomyositis (JDM) had been proposed by Buderus et al (9). They described an eight-year-old girl who had been diagnosed with both diseases and postulated a common genetic susceptibility and pathogenic mechanisms. Based on this earlier observation, Falcini et al (10) investigated the occurrence of celiac disease in a group of 14 children with JDM. They found a prevalence of one in 14 in their group, which was 20-fold higher than that estimated for the normal Italian population. Both groups recommended that endomysial antibody should be routinely investigated in children with JDM, even in the absence of gastrointestinal symptoms.

To our knowledge, the association between dermatomyositis and adult celiac disease has been reported only twice before (Table 1). The case reported by Marie et al (12) described a 
63-year-old woman who was diagnosed with celiac disease after having been treated for dermatomyositis with oral prednisone for approximately two years. Iannone and Lapadula (13) described a 48-year-old woman who was diagnosed with dermatomyositis after being diagnosed with celiac disease and being on a glutenfree diet. The patient was treated with prednisone and cyclosporine for one month before symptoms improved.

In the case presented, it is unique that the patient did not have overt gastrointestinal symptoms and that both the dermatomyositis and celiac disease remitted in response to gluten withdrawal. Although our patient did receive two doses of pulse methylprednisolone when the diagnosis of dermatomyositis was first established, she was never placed on continuous steroid treatment. Furthermore, the gradual improvement in her symptoms occurred only after gluten restriction was initiated, and dermatomyositis remained in remission with a gluten-free diet. After dietary modification was instituted, a subsequent duodenal biopsy showed an improvement of both villous atrophy and crypt hyperplasia and also reduced inflammation in the lamina propria. Although the muscle biopsy was not repeated, the clinical picture suggested a resolution of myositis.

The antibody test for endomysial antibody was negative. The test has a $90 \%$ to $95 \%$ sensitivity and specificity and is routinely performed in patients with suspected celiac disease (15-17). A false negative may explain this result. The duodenal biopsy, the small-bowel follow-through, the family history of celiac disease, improvement and resolution of her nutritional and vitamin deficiencies and improvement of duodenal biopsies on the gluten-free diet consolidated the diagnosis of celiac disease. Before we had the opportunity to perform the more recently developed antitissue transglutaminase test, the patient had moved back to her native country.

Both celiac disease and JDM share common HLA associations, including most notably the DQA1*0501 allele (18-20). HLA typing in our patient revealed the presence of the class II major histocompatibility antigens DR3 and DQ2 - a heterodimer encoded for by the DQA $1 * 0501$ and DQB1*0201 alleles. This heterodimer is thought to present gliadin-derived peptides to helper $\mathrm{T}$ cells, which trigger the changes leading to the enteropathy. These antigens are found in $95 \%$ of northern Europeans with celiac disease. Similarly, genetic studies in JDM have shown increased frequency of B8, DR3 and the DQA1*0501 allele. The common HLA type in these two conditions suggests a related immune-based susceptibility. In addition, while genetically susceptible to both disorders, the concurrence of both entities in our patient over a short period of time may suggest a common antigenic stimulus, which may be gluten or a novel intrinsic antigenic stimulus.

\section{CONCLUSION}

Our report suggests an association between adult celiac disease and dermatomyositis. We recommend that patients with newly diagnosed dermatomyositis be tested for celiac disease, given that the dermatomyositis may respond to a gluten-free diet. Further studies to determine the prevalence of celiac disease in patients with dermatomyositis, to find a potential common antigenic susceptibility gene or antigenic stimulus and to determine the effect of a gluten-free diet on dermatomyositis, seem indicated.

ACKNOWLEDGEMENTS: Dr Bitton is a research scholar of the Fonds de la Reserche en Santé du Québec.

\section{REFERENCES}

1. Callen JP. Myositis and malignancy. Curr Opin Rheumatol 1994;6:590-4.

2. Trier JS. Celiac Sprue. N Engl J Med 1991;325:1709-19.

3. Troncone R, Greco L, Auricchio S. Gluten-sensitive enteropathy. Pediatr Clin North Am 1996;43:355-73.

4. Godkin A, Jewell D. The pathogenesis of celiac disease. Gastroenterology 1998;115:206-10.

5. Counsell CE, Taha A, Ruddell WS. Coeliac disease and autoimmune thyroid disease. Gut 1994;35:844-6.

6. Sategna-Guidetti C, Bruno M, Mazza E, et al. Autoimmune thyroid diseases and coeliac disease. Eur J Gastroenterol Hepatol 1998;10:927-31.

7. Vilppula AH, Aine RA. Polymyositis associated with several immunological disorders. Clin Rheumatol 1984;3:533-9.

8. Evron E, Abarbanel JM, Branski D, et al. Polymyositis, arthritis, and proteinuria in a patient with adult celiac disease. J Rheumatol 1996;23:782-3.

9. Buderus S, Wagner N, Lentze MJ. Concurrence of celiac disease and juvenile dermatomyositis: Result of a specific immunogenetic susceptibility? J Pediatr Gastroenterol Nutr 1997;25:101-3.

10. Falcini F, Porfirio B, Lionetti P. Juvenile dermatomyositis and celiac disease. J Rheumatol 1999;26:1419-20.

11. Henriksson KG, Hallert C, Walan A. Letter: Gluten-sensitive polymyositis and enteropathy. Lancet 1976;2:317.

12. Marie I, Lecomte F, Hachulla E, et al. An uncommon association: Celiac disease and dermatomyositis in adults. Clin Exp Rheumatol 2001;19:201-3.

13. Iannone F, Lapadula G. Dermatomyositis and celiac disease association: A further case. Clin Exp Rheumatol 2001;19:757-8.

14. Ferguson A, Arranz E, O'Mahony S. Spectrum of expression of intestinal cellular immunity: Proposal for a change in diagnostic criteria of celiac disease. Ann Allergy 1993;71:29-32.

15. Unsworth DJ, Brown DL. Serological screening suggests that adult coeliac disease is underdiagnosed in the UK and increases the incidence by up to $12 \%$. Gut 1994;35:61-4.

16. Burgin-Wolff A, Gaze H, Hadziselimovic F. Antigliadin and antiendomysium antibody determination for coeliac disease. Arch Dis Child 1991;66:941-7.

17. Ferreira M, Davies SL, Butler M, et al. Endomysial antibody: Is it the best screening test for coeliac disease? Gut 1992;33:1633-7.

18. Sollid LM, Thorsby, E. HLA susceptibility genes in celiac disease: Genetic mapping and role in pathogenesis. Gastroenterology 1993;105:910-22.

19. Houlston RS, Ford D. Genetics of coeliac disease. QJM 1996;89:737-43.

20. Howdle PD, Blair GE. Molecular biology and coeliac disease. Gut 1992;33:573-5. 


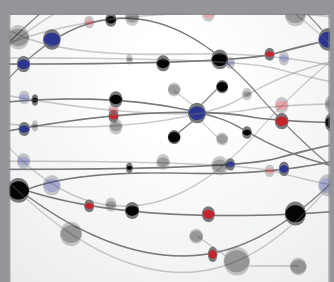

The Scientific World Journal
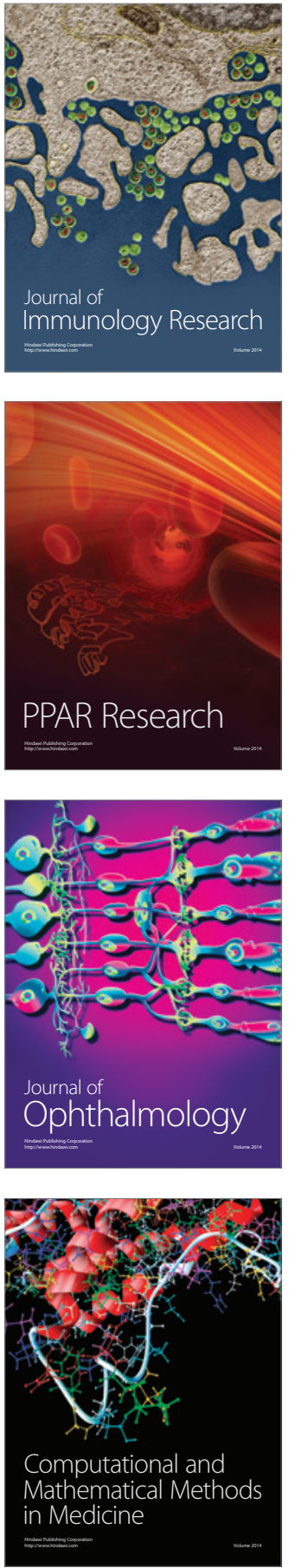

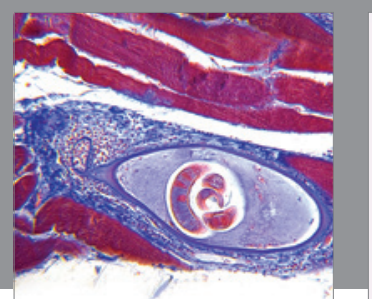

Gastroenterology Research and Practice

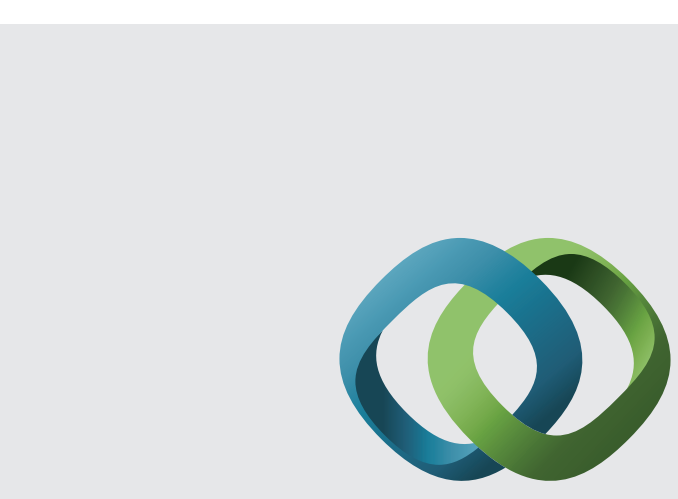

\section{Hindawi}

Submit your manuscripts at

http://www.hindawi.com
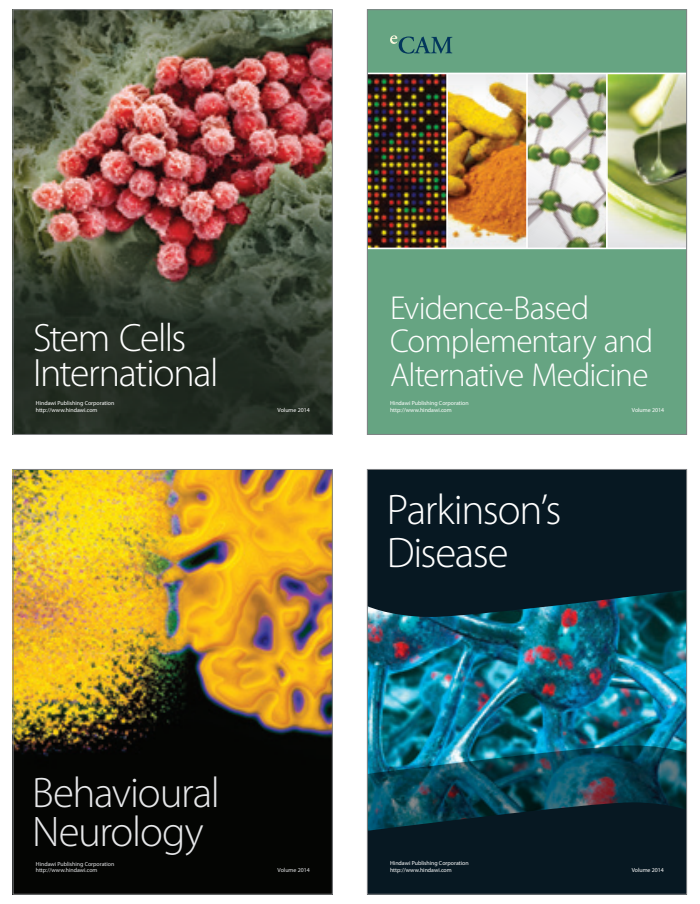
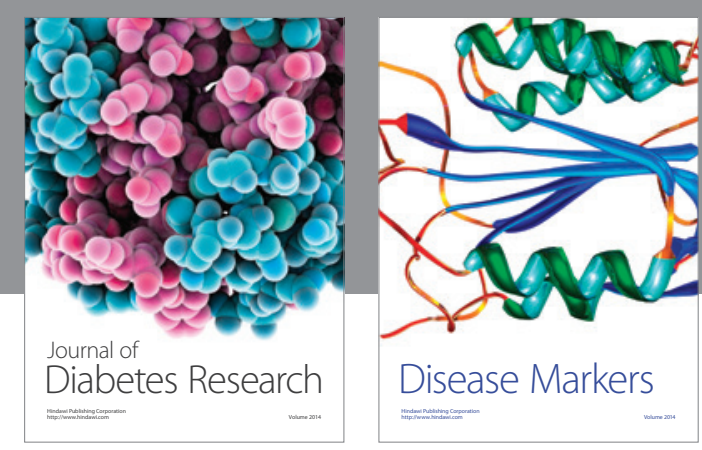

Disease Markers
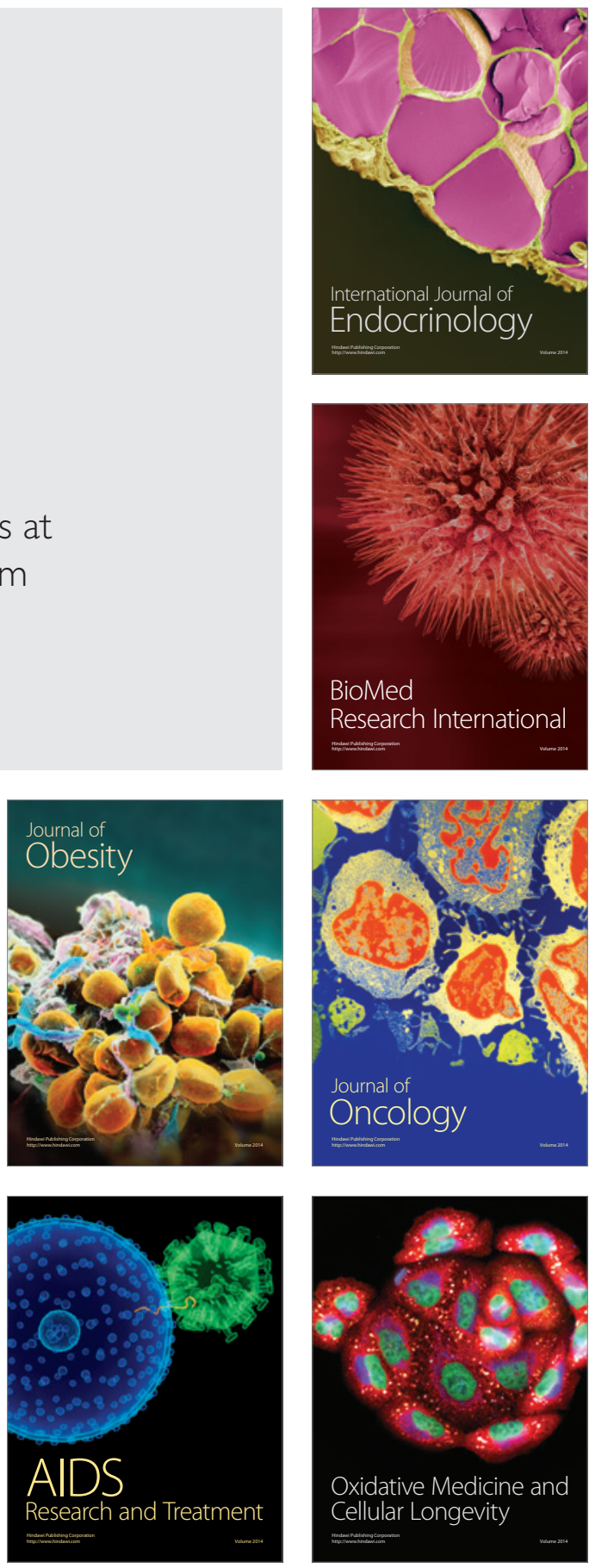